InOdia $\quad \begin{aligned} & \text { InMedia } \\ & \text { The French Journal of Media Studies }\end{aligned}$

7.1. $\mid 2018$

Visualizing Consumer Culture

\title{
Commodities, the Visual and the Senses: Perfume Editorials in High-End Fashion Publications in the 1970s
}

Alice Morin

\section{CpenEdition \\ Journals}

Electronic version

URL: http://journals.openedition.org/inmedia/1484

DOI: 10.4000/inmedia.1484

ISSN: 2259-4728

Publisher

Center for Research on the English-Speaking World (CREW)

Electronic reference

Alice Morin, « Commodities, the Visual and the Senses: Perfume Editorials in High-End Fashion Publications in the 1970s », InMedia [Online], 7.1. | 2018, Online since 20 December 2018, connection

on 08 September 2020. URL : http://journals.openedition.org/inmedia/1484 ; DOI : https://doi.org/

10.4000/inmedia.1484

This text was automatically generated on 8 September 2020

(c) InMedia 


\title{
Commodities, the Visual and the Senses: Perfume Editorials in High- End Fashion Publications in the 1970s
}

\author{
Alice Morin
}

\section{Introduction}

1 Perfume in its visual form is very much part of our everyday lives. Appealing to emotions and sensations, perfume-related images more often than not reveal thoughtful, even sometimes cutting-edge visual research, yet are nevertheless democratizing fragrances and granting them a very wide reach. The roots to this phenomenon, I argue, go back to the 1970s. During this decade, the visualization of perfume became a focal point of interest in the magazine press, through multiplied advertising campaigns but also, more of interest to this paper, in editorial content. In particular, as perfume (and its symbolism) has long been intertwined with fashion, from this turning point of the 1970s, it has regularly been the object of esthetic and symbolic attention in images produced by fashion magazines.

2 Amongst such magazines, I focus specifically on Vogue and Harper's Bazaar. Together, they hold a unique position in the field of the fashion press: as high-end publications, they are distinguished by said production of properly "editorial" images, as opposed to advertisements-which they also carry but do not produce-and rather integrate later in their layouts in spaces bought for that intent. The images under study in this article are editorial photographs, which are specific content produced by and for the magazines, in which they hold a central position. They are also part of photographic series, located in the "editorial well," "that is at the heart of the magazines, which does not carry advertisements. 
3 Such a central position (literally and symbolically) does not diminish the importance of advertisement in the deeply capitalistic ecosystem that rules consumer's magazines such as the ones of interest here. Quite the contrary, as demonstrated by many media scholars, ads, rather than subscriptions and sales, still represent today the main source of revenue of magazines, as they have since the beginning of the 20th century. ${ }^{2}$ However, the presence of this brand-driven content means that it is, and was, all the more crucial for editorial content to distinguish itself from it, and to establish a "voice" for the magazine producing it; a voice which editorial (photographic) productions altogether incarnate, shape, and drive. Mainstream publications such as Vogue and Harper's Bazaar-well-established (they were respectively founded in 1892 and 1867) and well-integrated in the press industry-heavily rely on this tradition. Although the porosity of the delineation between ads and editorial content is not as strict as they would like it to appear ${ }^{3}$-as the increasing closeness of both kind of images in form and substance, from the 1970s on, points to-editorial productions still "dominate" in their pages in terms of the value granted to them. Thus, for these magazines, they also represent a favored field of experimentation in implementing strategies to stay relevant, to negotiate their outlook on a changing world all the while changing little themselves-as part of a well-established tradition and in line with their role as a preserver of morality until the $1950 \mathrm{~s}^{4}$-and, mostly, to feed an enduring system, changing only in surface, ultimately serving itself and its own success.

In the 1970s, Vogue and Harper's Bazaar, which had already acquired the status of cultural references, where in a delicate place: starting in the late 1960s, they had reached an unprecedented readership ${ }^{5}$ but had also just undergone a period of destabilization as will be discussed below. The strategy used in the seventies to deal with these new challenges included perfume-related spreads. Indeed, this article stems from the observation that, in the pages of both these high-end, uniquely positioned magazines, the presence of perfume suddenly grew into an important and carefullycrafted category. I thus argue that this new interest in the visualization of fragrances illustrates the new stance adopted by magazines to interact with the world and society.

That cultural objects such as these magazines chose to showcase perfume in the mid-1970s also seems to indicate that fragrances' troubling quality of the invisible resonated with their concerns at the time. Well-established and transdisciplinary studies on perfume underline its "intimidating" allure. ${ }^{6}$ Perfume touches upon the realm of the mysterious, the intimate, and the unarticulated-the latter referring, here, to a quality that is impossible to articulate. The process of crystallizing such qualities mobilized the aesthetics and the discourses of the magazines, but also the social, economic, and even political issues of the period, as their oscillation between aesthetic research and implacable commercial necessities also had, among other things, implications for women's representations.

6 The magazines' interest in perfume enlightens us on the fashion photography of the time, and on the stakes at play in its production. It also illustrates the mechanisms of the perfume and fashion industries, and how they intersect. Finally, magazines taking up perfume and turning it into editorial images and new visual narrative allows us to better grasp the strategies they use to adapt to a new period, to create a new paradigm of representation and, in the larger perspective, offers a striking example of the mechanisms of the strong, resilient (capitalistic) editorial system that is at their core. 


\section{The 1970s as a Turning Point in Perfume, the Press, and American History}

7 The mid-1970s, during which time the perfume editorials under scrutiny emerged as a strong trend, represent a moment when the industries of perfume, fashion, and the (fashion) press both were destabilized and expanded, in light of more general changes in political and social areas.

For the perfume industry, the decade was pivotal. Perfume historians have shown that throughout the 20th century, perfume creation and diffusion had come to depend on fashion houses. ${ }^{7}$ The connection between nascent fashion brands and fragrances was not necessarily a mutually beneficial one: starting in the 1910s, brands realized the potential fragrances held to improve their image, their accessibility, and their aura of mystery and glamour, as stated by Annick Le Guérer. ${ }^{8}$ It was then, at the beginning of the $20^{\text {th }}$ century, that the couturiers launched their first perfumes with the notable example of Paul Poiret. They were also the first to market their fragrances by increasingly using visualization in their approach, as demonstrated by the first illustrated ads and by an emphasis on the bottle. ${ }^{9}$ While perfume retained some of its "magical" qualities-it was and still is, to a certain extent, associated to eternal life, godly essence and, medicinal properties-it also became somehow desacralized and more accessible as it started to become part of people's everyday lives.

Through the rise of its visual treatment, perfume was also increasingly detached from its smell and attached to its image, even though it still retained its proximity to the flesh, through the intrinsic quality of being worn on one's body. At the same time, technological advances made the perfume-making process more sophisticated and increasingly incorporated chemistry. These evolutions culminated in the 1970s, with such great names in fashion as Dior, Yves Saint-Laurent, and Chanel, who relied heavily on perfumes to be access products to their more expensive lines of clothing. Thus, seeds were planted for a global market that fully blossomed in the 1980s with European luxury perfumery "invading" the American market-to the effect of olfactory, visual, and narrative leveling-a process of internationalization already palpable by the mid-1970s. ${ }^{10}$ For the cosmetic industry, which was in general more and more associated with the great names of fashion, the 1970s were thus indeed an "in-between" moment when creative visual and olfactory research nevertheless announced standardization and "hyperconsumerism."11

10 The same period was also a defining moment for fashion as we know it, in the wake of the 1960s' upheavals. These tumultuous years saw clothing, especially in the United States, grow into both a national industry and an exemplary mean of individual expression, as opposed to the means of class differentiation as it was before; in this process, the uses of dress by political and countercultural movements were instrumental..$^{12}$ For a brief moment, individual and collective appropriations of fashion took over a rigid code of dressing disseminated in no small part by fashion magazines, acting as guides, which were then destabilized.

11 The 1970s were heir to the sixties in more than one way, but they were also witness to a gradual return to the status quo. As fashion historian and curator Valerie Steele has noted, fashion trends do function in reaction to previous periods rather than as mirrors of society-although they indeed reflect current social issues. ${ }^{13}$ She observes that there 
was no spectacular beginning to the 1970s in terms of fashion. Instead, political ideas and events set in motion in the previous decades started to diffuse in dress, while at the same time a sense of revolt against the strong (and mythicized) sixties unfolded. ${ }^{14}$ of peculiar interest to the study of the fashion press is the mainstream diffusion of the idea of "choice" and expression through fashion, which can be put in parallel with antifashion trends-in short, people were demonstrated varied fashion tastes, which challenged magazines' historic role as instructors of fashion and manners. ${ }^{15}$ Steele explains that "the arbiters of fashion risked being dismissed as 'fashion fascists' if they dared tell women what was 'in' or 'out.' As a result, fashion journalists quickly adopted a new language of 'freedom' and 'choice". ${ }^{16}$ Nonetheless, out of this contested moment emerged, at the end of the decade, a reaffirmed albeit transformed authority, to which the evolution of magazine's editorial production, which strongly manifested itself in perfume editorials, attests to. It further illustrates the shift from an authority based on strict social rules to one relying more heavily on desire-a never fulfilled, always refueled desire which came to guide the cultural trends of most of the 1980s.

It is interesting to note how these processes strikingly echo historian Edward Berkowitz's account of the 1970 s as a period that witness the simultaneously implementation of 1960s utopias and the planting of seeds for the 1980s. Such a strain would account for competing events such as women's access to the job market-with trouser suits becoming a staple in feminine wardrobes in its wake-the 1972 Supreme Court decision Eisenstadt v. Baird making contraception available to non-married couples and the 1973 Roe $v$. Wade decision making abortion constitutional in the U.S., as well as the momentum of the gay rights movement on the one hand; and the recommitment to laissez-faire economy and the stirrings of the conservative backlash, particularly noticeable in televised popular culture, on the other hand. All these events did take place at the time of an unprecedented "crisis of confidence," a moment of defiance of all forms of authority, whether they were political, economic, medical, or even spiritual. ${ }^{17}$ This climate of anxiety, which radically differed from the 1960s idea of looking towards the future, definitely marked the end of the "years of hope," 18 and created the perfect context for turning to nostalgia, fantasy and self-proclaimed yet restrictive "freedom"-all of which were elements exploited in the fashion press professionals to create images of perfume, and which were further developed in the 1980s, generally characterized by the triumph of neoliberal, free-market economy and its values of hedonism, escapism, and renewed optimism. ${ }^{19}$

13 All of these changes were perceptible in magazines. Indeed, while its main audience members (women) were themselves experiencing changes in their position, fashion magazines had to adapt their formula and became major actors in this shift: they reported on this newfound liberty, with the trial and errors it induced, as demonstrated by new columns on women's sex lives, work lives, new family lives, and money managing that started to appear in the late 1960s. Such often-proclaimed unabashed optimism was regularly counterbalanced in their pages: anxiety, for one, is particularly perceptible. Regular features on rape, alcoholism, abortion, and the potential loneliness of their readers abounded during that time. For instance, Harper's Bazaar's March 1976 issue dedicated to "America's Single Woman" "incidentally" features articles entitled "The Insecurities of Being Single," "How to Make Your Apartment Safe," "Anti-Rape Technique," amongst other examples. This "back and forth" movement between liberalism and conservatism attests to the need for fashion magazines, which are altogether consumer magazines as well as women magazines and, 
to a certain extent, "news" magazines, to channel political, social and cultural fluxes. As is often the case, their photographic productions played an ambiguous role in both reflecting and shaping these ongoing shifts, making them accessible to a large audience and appropriating them while doing so.

Both titles' uneasiness and their ambiguous stance partly results from their function as mediators between the "multiple audiences" of readers, advertisers and fashion professionals which they were trying to please-as anthropologist Brian Moeran puts it, ${ }^{20}$ all groups moving in diverse, even contradictory directions. But in the end, magazines exemplified the phenomenon of "recuperation." ${ }^{21}$ In his study on punk fashion, sociologist Dick Hebdige coined the term of "recuperation," akin to a form of "co-optation." Simply put, it can be broken down into different steps. The first is the birth, out of rebellion, of a stylistic movement presenting itself as "anti-fashion." After a while, this movement inspires fashion's institutions which reuse several of its key elements and codify them as signifying of this trend. Finally, these markers are reassociated with the original ideas in the mainstream and are, thus, quickly emptied of their subversive strength. According to Hebdige, this process came out in full force during the 1980s. It was thus in the making in the 1970s, a period during which it manifested, in the magazines, through a gap between their liberated discourses (with the aforementioned articles including forward-looking vocabulary and ideas) and the normative dimension of women's general image which emerged from this period onward. This ambivalence is particularly well demonstrated by research led on perfume and on its associated qualities at the time, which then becomes exemplary of an entire system and how it negotiates changing circumstances.

In fact, all these connected events account for why, in the 1970s, perfume-related editorial series began to appear regularly in Vogue and Harper's Bazaar in an eyecatching way. Before that, fragrances were regularly present in these publications, in the beauty section where they were the subject of bi-annual trend reports ${ }^{22}$, yet their visual treatment was relatively unremarkable, featuring bottles on a plain background, often in black and white. From the early 1970s and especially since 1975, they, in turn, manifested themselves either in transformed and modernized traditional sections (beauty and fashion) or in compelling new photoshoots that staged different fragrances by evoking the feelings, sensations and memories conjured up by their smells. ${ }^{23}$

The two following sections are dedicated to the study, in this transitional moment, of all fragrances-focused photographic editorial series in issues of Vogue and Harper's Bazaar running from 1974 to 1985 , to identify major representative trends in this period. Some of the most emblematic photoshoots are also analyzed more closely to illuminate the processes magazines put in place through the use of perfume in their pages. Such an analysis, oscillating between quantitative and qualitative, is considered in light of the aforementioned context, of utmost importance to magazines, as previously underlined: as stated by Carolyn Kitch, although the press does not reflect a moment in history, it is nevertheless shaped by it while also contributing to shaping it and the memories of it. ${ }^{24}$ The chosen primary corpus, in particular, represents, as I have tried to demonstrate, altogether an economic system, the barometer of a certain "zeitgeist" and an exception in that they are high-end and thus fantasy-inducing oriented magazines, as is the fashion industry itself. The use of secondary sources originating from media studies, but importantly also, from fashion studies, testifies to 
the importance of understanding fashion to understand the fashion press, as they share economic interests and certain common mechanisms.

\section{Sketching "the" (American) Woman through Perfume Editorials}

17 Through in-depth observation of the photo series staging perfumes, three different categories emerge. The first one consists in the presentation of perfume novelties in the trend and beauty pages. This category has been firmly established for decades, mostly for commercial reasons, but started showing undeniable signs of aesthetic audacity from approximately 1975 onwards, through its experimenting with such graphic elements as typography, image placement and, more generally, with photographs and layouts. For instance, Vogue's "Fragrance is Faster, Scent-ABC" by journalist Camille Duhé in the May 1976 issue uses drawn color waves superimposed on the text and photographs to emulate the scent's travelling smells. Harper's Bazaar's "Holiday Seduction Guide... Andy Warhol's 'Fragrance"' (December 1979) cheerfully relies on both the Pop artist's use of unexpected, vivid colors and on transparencies reminiscent of the fragrances' liquid itself.

18 The second category, emerging around the same time, represents a real novelty. It consisted in including perfumes, referenced in the captions, into more traditional fashion series. For example, in the editorial series "Night Moves" by photographer Chris Von Wangenheim published in Vogue in November 1977, the lead paragraph reads: "Different moves for different evenings...the new nightlife-dressing is all about options. Whether it's dinner à deux in your living room, a black-tie benefit, or all the fun in between, there are degrees of dressing..." It stages clothes, shoes, jewelry and... fragrances, not visible but included in the captions as just another accessory to be added to one's look-in the same way, make-up was increasingly captioned. These photographs testify to the fact that perfume had become a commercial selling point, the finishing touch to a look, a non-essential but definite part of a (life)style.

The third category is the most creative and the most elaborate in its staging. It consisted of photographs attempting to translate into images the characteristics, emotions, and memories evoked by fragrances. Helmut Newton's unusual, striking and crude photographs for "The Story of Ohhh" (Vogue, May 1975) emphasize skin texture and movement. Each photograph is accompanied by two sets of captions which read respectively "The Bareness" and "The Fragrance," the latter providing commercial information about the perfume while also putting into words the effect of the fragrances which inspired the photograph's atmosphere. This "third category" of editorial photographs included spreads on fashion, central to the photographs, but in which perfume played a real part in the mise en scène, as if it was a "character." These series of photographs are the least common of the three categories-about one or two per year in each magazine since 1975, most frequently in the May and November issues. Yet they are the strongest and most evocative ones, and thus of particular interest to this paper.

20 All three forms are complementary and, taken together, are indicative of a renewed interest in the power (commercial and beyond) of fragrances at that time. Considering fragrances from different angles and for different purposes, these three types of 
representations underline the recurring traits used to visualize and embody perfume. Amongst these recurring traits, perfume series almost always focused on the bodyoften a denuded one-at a time when commenters have noted-and criticized-the growing use of nudity in the representation of women. ${ }^{25}$ Perfume-related photographs also strongly relied in one way or another on light, as if to express the air-modifying quality of perfume. A sizable number of words in the paratext was used to conjure up feelings and emotions brought forth by perfume. Finally, these mises en scènes put a special emphasis on several of the five senses at the same time, even on all of them on some occasions. ${ }^{26}$

21 Besides, it is important to note that the production of these series is part of the renewed and reinforced interest of fashion magazines in beauty. In 1979, the beauty pages started to count as many pages as fashion spreads, before this tendency reversed later in the 1980s. This great interest in beauty, beyond its commercial motives, was consistent with the magazines' desire to regain an authoritative status, as providers of adapted and updated advice on fashion and beauty. Regarding perfume for instance, magazines now manifested a definite emphasis on "personal communication" and on fragrance as an empowering device for women. In the texts, editors often insisted on a scent's distinctive and unique qualities, and, over the years, they offered more multiple guidelines on how to choose one's own perfume under their expert lead.

Thus, fashion magazines inscribed perfume in a post-1960s narrative that advocated women's emancipation, even though the reality of the content differed from this discourse-as the excessive recourse to nudity at the time demonstrates. Nudity and seduction were almost synonymous in perfume editorials, conveying a gendered vision of woman as both dangerous (because of her seduction) and in need of a man, making these portrayals of women not quite as disruptive as they claimed to be. Furthermore, there was never any point at which the mainstream norm of the heterosexual couple was challenged.

All these representations took part in the sketching of a general vision of "the" woman, presented as a model to the audience, and thus calibrated with the targeted groups in mind. In the mid-1970s, this model represented a more independent and empowered woman-and it also included more ethnic diversity. Yet it was still circumscribed to a gendered and national vision of femininity: the favored "look" of that period was "allnatural," a notion long associated with American fashion. ${ }^{27}$ In photographs, one clearly notes recurring water themes, and of daytime photoshoots taking place in the open-air. This natural, simple and all-American vision of women and of their ideal-and idealized -life was evenly counterbalanced by a profusion of products, notably perfumes, from which they were supposed to choose. This is underlined by the injunctive element in such photoshoots; women were free to choose their products, but they still had to consume. This unabashed, repeated ode to abundance as a material as well as spiritual model highlights how much these well-established magazines relied on the longstanding narrative of consumerism as patriotism-at a time when the American way of life was still very much used as a political tool and economic imperative, in the context of the debacle of the Vietnam War and the beginnings of a serious financial crisis. Thus, this "new" woman was branded as a consumer, and simultaneously as an American, in a very explicit (and traditional) way-as demonstrated by cover titles such as "The Most Beautiful Bodies in America" [emphasis added] (Harper's Bazaar, May 1980). 

indeed nothing new in the realm of popular culture and more specifically in the fashion press, which owes its very existence to the very effort to do so, as studies women's magazines' discourses in the 19th century, publicity in 20th-century Vogue, and various other case studies on women and magazines demonstrate. Nevertheless, the new representations and afferent discourses, in the 1970s, seem to point to a change of scale of this model, owing a great deal to the historical context, in which the political and the cultural are working hand in hand to construct a coherent pendant to the capitalist economic model. This burst of soft power, initiated in the 1940s at the end of World War II, did regain much vitality in the 1980s with a renewed diplomatic polarization but also, with a growing globalization opening new markets and new potential output to this "American-branded" model. ${ }^{28}$

\section{Aesthetics of Profusion: Words and the Five Senses}

It is in such context that the specificities of perfume editorials unfolded. The new aesthetic it inspired and embodies most vividly can be analyzed as a response to all elements of context mentioned this far, and it also manifests attempts of responses to such a destabilization/re-stabilization dynamic, a sort of answer offered to various questions raised about gendered, national identity crisis for which perfume proved to be an ideal vessel.

Through this lens, some recurring elements in perfume photoshoots appears particularly noteworthy. For instance, there are numerous features and photographs linking women and flowers in the photographs of the period in Vogue and Harper's Bazaar. This obsession enters into a dialogue with changing views on sexuality, and can be read as a way to juxtapose purity and sensuality. This trend even expanded beyond the perfume pages to many unrelated photoshoots. Harper's Bazaar's May 1982 "Super Scents... Sensational Floral Fragrances" photographed by Bill Silano epitomizes how both levels of signification coexisted in one series: it consists of close-ups of flowers pistils, reminiscent of women's genitalia in a most classical manner, with their curvaceous lines intertwined with the stiff perfume bottles. However, their white backgrounds and clean grey lines evoke a certain cleanliness consistent with the obsession with health and hygiene characteristic of the United States. Series such as these are also interesting in that they appeal to at least two of the five senses-in this example, sight and smell-all five senses being solicited elsewhere.

Food and beauty, for instance, were often linked in photo series, similar to fragrance and wine. In November 1979, Vogue presented a photo-story by Andrea Blanch, blandly entitled "Fragrance/Lingerie: An Intimate Association" and apparently chronicling the love life of several modern-and well-off-women. Perfume is present throughout, in the title as well as in the bottles which are reflected endlessly on a mirror coffee table where they are set up as the pieces for a game of chess. Smell is also appealed to through the sensuality of the bare skins, of women and men. Touch and hearing are meant to be titillated as well, with a chimney fire whose warmth can almost be felt and whose crackle can almost be heard. Taste is evoked, with a dinner table set for manyplates filled only with vials instead of food. Finally, the importance of sight is underlined, as the most obviously mobilized of the five senses in photography, with the use of mirrors, the staging of an improvised lovers' photoshoot, the glittering textures 
of dresses, with moist skin and even with a parrot appearing in all its bright colors in one of the shots.

Other series use less obvious associations, as in Harper's Bazaar's “The Bath: A New Beauty Environment" (April 1976, by Bob Stone), appealing to smell through perfume but also to touch and sight through the bathtub's surface-all playing on liquid elements to provoke strong sensations. Conversely, more obvious associations are also employed, such as in Vogue's "A Certain Luxury/Taking the Time for Fantasy" (October 1980 , by Denis Piel) in which the model, whose fragrance the captions indicate, goes about licking her lips after taking a bite of her canapé in bed, or sniffing dreamingly at a rose. Such images represented a strong trend in the 1970s and another example of how hedonism, as a newfound freedom, and consumerism were inexorably linked, in visual as well as in textual ways.

The paratext was indeed very important at the time, as its quantity increased while its vocabulary broadened. Indeed, keywords such as "independent," coupled with "fresh, sun, floral" in the mid-1970s, and later in the decade, "sexy, bare, soft," reinforced the magazines' ambiguous position towards perfume and women, constructing a contrasted image of sexuality and of femininity. The paratext also started to indicate a regained injunctive tone later in the decade with strong urges to follow the indications provided by the magazines.

In her quantitative study on "Verbal Representation of Fragrances," psychologist Celine Manetta insists that, contrary to a certain popular belief as to the un-utterability of the scented realm, our vocabulary to refer to perfume is abundant. She writes that "the descriptions of fragrances are numerous and rich." ${ }^{29}$ Interestingly, the "scented vocabulary" even spread to the pages not representing perfume, with terms such as "amber, floral, fragrant" to be found in feature articles, as qualifiers for instance, or in general beauty pages. This seems to indicate yet another instance of the mobilization of the five senses. This would lead me to posit that text, whose mediating function is crucial, in this way participated actively in the construction of visual stimulation in fashion magazines. In such mobilization, words and images were working together, which was not necessarily always the case in fashion magazines. ${ }^{30}$

More than mediation and articulation, it appears that text stands as a key element in making the invisible (perfume) visible. This is supported by the fact that almost all perfume series contain a great amount of text. For example, journalists sometimes used personal recollections. Vogue's May 1979 “Fragrance-Your Personal Signal” by photographer Duane Michals appears as a textbook example of the treatment of perfumes in editorial photographs. It combines sexualized nudity (an undressed couple staring at each other), flowers (a naked woman whose head is replaced by a bouquet), a visual narrative (several sequential shots presented linearly on one page), the presentation of perfume bottles, an emphasis on texture and the senses (an arresting image spread over two pages of a bottle smashed by a hammer and spilled on a dark surface) along with text in the form of the photographer's own handwriting detailing his personal impressions of perfume. This demonstrates how much perfume tended, at that time and in these pages, to be intellectualized. Such creativity and insistence on the elusiveness of personal experience could represent a counter-power to the overcommercializing of perfume, still in gestation in the mid-1970s, a trend represented, for its part, by the use of perfume as an accessory in fashion editorials. 

paralleled the attempts of fashion magazines at relating as closely as possible to their growing and more democratized readership, a desire translated into the introduction of more realistic photographic editorials and features. This is evidenced by the recurrent use of real-life role models, with the insistence that "nobody's perfect" in eponymous articles pointing out the flaws of such role-models, and by a more general preoccupation with savings, bargains, and appropriate attire for real-life situations. In reaction, the "fantasy" series, in which perfume inserted itself as easily as in the everyday-life inspired series, grew more fantastic, and drew more heavily on the imaginary, nostalgia, exoticism and opulent luxury, opening a window of non-reality on paper, a space where everything and anything was possible, which, one could argue once more, may have touched readers more closely than the more realistic features.

A new relationship to femininity, to sexuality and, beyond, to images and their evocative power is thus sketched through these recurring stylistic devices, opening up a space for resistance to well-known narratives and the tools usually used to express them. At the very least, the visual richness of perfume editorials in the 1970s makes certain tensions-underpinning magazines by essence, as testified to by their complicated relationship to their "multiple audiences"-explicit and potentially 
productive. Nevertheless, a process of recuperation was already at play, and soon, by the mid-1980s, in a renewed context of mass consumption, the transformation of perfume into an accessory was completed-as was also the case for art, music, which were also "accessorized." Observing later 1980s photographic series on perfume, one can note that the functions of fragrances had shifted, or, in a way, had concentrated: they conjured a lifestyle, of which fragrances had become very much a part, one spelled-out for the consumer, with a genealogy of influences, a range of role-models, a precise idea of what to wear, what to listen to, who to be.

\section{The Entanglement of Commodification and Visualization in Perfume Editorials} towards style in the 1980s, when magazines tried to sell more and more clothes without repeating themselves in terms of editorial creation. This paper's analysis of treatment of perfume in high-end fashion magazines indicates that a logical evolution led from propositions of the turning point of the 1970s to this profitable shift to style. Indeed, in historian and sociologist Stuart Ewen's view, style is precisely a "unity of opposites" represented by the cohabitation of reality and fantasy, between the ordinary and the extraordinary, the effortless and the effort. Style is the attempt to mend this divide, generally on the surface of an image. With perfume, we have an example of how style has gradually become commodified. Furthermore, in an ever-rising context of hyper consumerism, the consumer's involvement in the process is accentuated, as seen above with editorial photographs of perfume and the five senses trying to pull the readers in. In the field of marketing, another good example of this participatory emphasis might be observed in the implementation, in the late 1980s, of store smell design, that is, spraying perfumes in stores to make the general mood more conducive to consumption.

It is interesting, however, to note that according to sociologist Anne-Sophie TrébuchetBreitwiller, perfume is favored most when it is not in fashion. ${ }^{34}$ From the 1980 s on, commenters have observed a growing standardization of perfume which was by then mass-marketed. This standardization, symptomatic of the then widespread model of attempting to reach the widest audience possible, affected smell, which was reduced to a general idea of what one thinks a given smell should resemble, foregoing nuances. It also affected visual representations, which multiplied, yet, in the same way, ended up associating clichés to odors (rose with love, musk with sensuality, to name a few). In the process, vocabularies and imaginaries were impoverished, reduced to caricatures of 
themselves. ${ }^{35}$ Stories told too many times dried their source of inspiration, and the appeal to consumers' emotions, too often called upon, fell short, or so it would appear.

This impoverishment, together with the invasive character of these new ways of consuming seem to exemplify the cycle of recuperation as proposed by Hebdige very early on. But I would argue that what it actually accomplished was to fuel a larger system of fashion images, one of pleasure, a system described by Edgar Morin and Gilles Lipovestky as operating on the fascination of the willing reader, avid to get more, and consequently constantly producing old-new images; ${ }^{36}$ a system aware that it is selling feelings rather than products, and thus playing on that dimension to provoke, consciously or unconsciously, powerful yet personal visual stimuli, through a decadesold perfected and finally autonomous system of referencing and intericonicity (a visual form of intertextuality and referencing).$^{37}$ The treatment of perfume ultimately serves and strengthens the magazines' editorial productions' own cause by taking part in an endless, fascinating game of mirrors resorting to senses, memories and cultural references to engage the reader in an uneven dialogue directed at the consumption of more fashion images. The fact that seduction, consumerism and authority came together in perfume editorials resonates powerfully with this evocative power of fashion photography-and could contribute to explain editorial infatuation with perfumes' staging during these times of changes.

\section{Conclusion}

41 The visualization of perfume has long been associated with fashion, the fashion industry and the press. In this respect, the fact that both industries used one another in the 1970 s seemed compelling and potentially instructive, since trends notable in perfume editorials tend to expand to other types of fashion editorials, and since, in this article, the former has been treated as a sort of metonymy of more general editorial photographic strategies used by magazines in the period considered. A close analysis of the images produced at that time has indeed revealed that this decade, traditionally represented as an in-between time, did assimilate previous upheavals while ushering new behaviors, creating a unique editorial body of work in the process. Observation of the corpus has outlined a convincing portrait of the fashion press industry and of the mechanisms behind the creation of these images, almost always guided by commercial interests but needing to make themselves attractive to stay relevant, always weaving the visual and the commodities further in a perpetual process of adaptation to change.

The very essence of the subject of these representations, perfume itself, has offered fertile ground for formal and substantial research operated in fashion images. This article's argument is that perfume editorials are exemplary in the way they have catalyzed hopes and anxieties in a potent appeal to various meaning-creating devices, such as recourse to the five senses through images and text. All the while, a channeling of the tension between abundance and choice through an American feminine figure that ultimately proved normative, has accomplished the same goal. Although the social and cultural norm palpable behind these images evolved very little in the end, the variations offered through visual propositions permitted by fragrances proved instrumental in maintaining, negotiating and re-reading it.

Yet, if perfume did seem like a fertile subject at that time, it has since suffered from exhaustion. The tensions then negotiated through representations of perfume have 
moved away from it onto other topics (such as, amongst many examples, roleplaying in the 1990s), and perfume editorials have now stopped being a space for risk-taking. I would contend that this fading partly has to do with the problem of temporality, which proves conflictual in the case of perfume-more so than for other fashion artifacts, as perfumes seek to be both atemporal and seasonal, when other goods are anchored in a shorter trend cycle. This is exemplified in the very magazines under study, for example by the repeated injunction to find one's "life companion" in a perfume, which is at odds with the promotion of novelty in the fashion and accessories pages.

This is one of the potential ways in which fragrances may oppose the traditional mechanisms of commodification. 1970s visual experiments have apparently failed to successfully exploit these and other possible forms resistance, which they often touched upon, to renew a system which is by definition enduring and conservative. It is nevertheless interesting to observe that today, niche, custom-made exclusive perfumery is inspiring consumers and magazines alike. ${ }^{38}$ Such a return to "authenticity," longer temporalities and to craft furthermore influences the entire fashion industry, as evidenced by a renewed interest in sustainable fashion, in artisanship and in the atemporal. This movement (trend or structural movement, time will tell) represents an alternative to the opposite tendency, which saw the 1980s' spirit of hyper-consumerism recast and amplified under the form of experiential marketing and the growing commodification of the consumers' private lives. From studying previous circumstances, it would seem that perfume has the ability to partake in either of these developments, or even to partake in both at the same time.

\section{BIBLIOGRAPHY}

Primary sources

Harper's Bazaar U.S. New York: Hearst Corporation, since 1867, 1974 through 1985 issues.

Vogue U.S. New York: Condé Nast, since 1892, 1974 through 1985 issues.

Steele, Valerie. Interview with the author. Fashion Institute of Technology of New York, April 2016. Secondary sources

Ballaster, Rosalind, Margaret Beetham, Elizabeth Fraser and Sandra Hebron eds. Women's Worlds: Ideology, Femininity and the Woman's Magazine. Basingstoke: Macmillan, 1991.

Beetham, Margaret. A Magazine of Her Own?: Domesticity and Desire in the Woman's Magazine, 1800-1914. 1996; Milton Park: Taylor \& Francis, 2004.

Berkowitz, Edward D. Something Happened: A Political and Cultural Overview of the Seventies. New York: Columbia University Press, 2006.

Chastagner, Claude. De la culture rock. Paris: Presses Universitaires de France, 2011.

Craik, Jennifer. The Face of Fashion: Cultural Studies in Fashion. London/New York: Routledge, 1994.

Cusset, François. La décennie. Paris: La Découverte, 2008. 
Ellena, Jean-Claude and Olivier Assouly. "Entretien/Jean-Claude Ellena, Le parfum à l'épreuve des marchés." Mode de Recherche 11, "Le Parfum", (2009/1): 3-8.

Evans, Caroline. "Street Style, Subculture and Subversion." Costume 31, (1997/1): 105-110.

Ewen, Stuart. All Consuming Images: The Politics of Style in Contemporary Culture. New York: Basic Books, 1988.

Gross, Michael. Focus: The Secret, Sexy, Sometimes Sordid World of Fashion Photographers. New York: Simon \& Schuster, Atria Books, 2016.

Hebdige, Dick. Sub-culture. The Meaning of Style. London: Methuen \& Co. Ltd, 1979.

Hill, Daniel Delis. As Seen in Vogue: A Century of American Fashion in Advertising. Lubbock: Texas Tech University Press, 2007.

Jones, Geoffrey. Beauty Imagined: A History of the Global Beauty Industry. Oxford: Oxford University Press, 2010.

Kitch, Carolyn. The Girl on the Magazine Cover: The Origins of Visual Stereotypes in American Mass Media. Chapel Hill: University of North Carolina Press, 2001.

Le Dantec-Lowry, Hélène. “To Speed Our Boys Home... Produce and Conserve. Share and Play Square. Home Front Propaganda and Food during World War II: Rewriting Gender?." Transatlantica, (2018/1) (to be published).

Le Guérer, Annick. "Le parfum, des temples égyptiens aux temples de la consommation." Mode de Recherche 11, "Le Parfum”, (2009/1): 9-15.

Lindner, Katharina. "Images of Women in General Interest and Fashion Magazine Advertisements from 1955 to 2002." Sex Roles 51, (2004/7-8): 409-421.

Lipovetsky, Gilles. L'Empire de l'éphémère: La mode et son destin dans les sociétés modernes, Paris: Gallimard, 1987.

--. "La société d'hyperconsommation." Le Débat 124, (2003): 74-98.

Manetta Céline, Edith Sales-Wuillemin, Audrey Gaillard and Isabel Urdapilleta. "Verbal Representation of Fragrances: Dependence on Specific Task." Journal of Applied Social Psychology 41, (2011/3): 658-681.

McDonald, Gay. "The Modern American Home as Soft Power: Finland, MoMA and the "American Home 1953' Exhibition.” Journal of Design History 23, (2010/4): 387-408.

Moeran, Brian. “More Than Just a Fashion Magazine." Current Sociology 54, (2006): 725-730.

Morère, Julie. “Intericonicity in Disguise in Madame Yevonde's Goddesses Series and Cindy Sherman's History Portraits/Old Masters." E-Rea. Revue Électronique D'études Sur Le Monde Anglophone 13, (2015/1): doi:10.4000/erea.4659.

Morin, Edgar. L'esprit du temps. Essai sur la culture de masse. 1962; La Tour-d'Aigues: Éditions de l'Aube, 2017.

O’Neill, Alistair. “Fashion Photography, Communication, criticisme and curation from 1975." In Fashion Cultures Revisited: Theories, Explorations and Analysis, edited by Stella Bruzzi and Pamela Church Gibson, 149-160. London/New York: Routledge, 2013.

Rain Bradstreet, Christina. Scented Visions: The Nineteenth-Century Olfactory Imagination. Thesis submitted for the Degree of Doctor of Philosophy in History of Art, Birkbeck College, University of London, 2008. 
Ritchie, Rachel, Sue Hawkins, Nicola Phillips and S. Jay Kleinberg eds. Women in Magazines: Research, Representation, Production and Consumption. New York: Routledge, 2016.

Scholes, Robert. “Afterword: Small Magazines, Large Ones, and Those In-Between.” In Little Magazines \& Modernism: New Approaches, edited by Adam McKible and Suzanne W. Churchill, 215-226. Aldershot: Ashgate, 2007.

Sonnac, Nathalie. “L'économie des magazines.” Réseaux 105 (2001/1): 79-100.

Steele, Valerie. “Anti Fashion: The 1970s.” Fashion Theory 1, (1997/3): 279-295.

Stamelman, Richard. Perfume: Joy, Scandal, Sin - A Cultural History of Fragrance from 1750 to the Present. New York: Rizzoli, 2006.

Têtu, Catherine. "La présence des parfums en marge des parfums de masse." Mode de Recherche 11, “Le Parfum”, (2009/1): 24-29.

Trébuchet-Breitwiller, Anne-Sophie. "Parfum et mode, l'histoire d'un paradoxe." Mode de Recherche 11, "Le Parfum”, (2009/1): 20-23.

\section{ENDNOTES}

1. The "editorial well" is the space, at the heart of the magazines, dedicated to the publication of editorial images, to the exclusion of other content, such as advertisements and even articles. Its constitution is the main activity of (fashion) magazines.

2. For a study on the importance of publicity in magazines' economy, see Nathalie Sonnac, "L'économie des magazines," Réseaux 105 (2001/1); for historical accounts of how advertising came to supplant readership as the foundation of this economy, see Robert Scholes, "Afterword: Small Magazines, Large Ones, and Those In-Between," in Little Magazines \& Modernism: New Approaches, eds. Adam McKible and Suzanne W. Churchill (Aldershot: Ashgate, 2007) or Rosalind Ballaster et al., Women's Worlds: Ideology, Femininity and the Woman's Magazine (Basingstoke: Macmillan, 1991).

3. The disjonction between both types of images, as fundamental as it is, relies little on form (as those playfully dialogue), but is rather to be found in the modes of production and in the ways of considering them. It is thus a more conceptual than formal distinction, and occasional hybrid experiment may come to light in magazines, merging fashion editorial and ads photographs-for instance, certain fashion series may feature only one designer and be a "disguised" ad; or magazines can produce advertorials. This draws attention on the double process of staging editorial content in magazines: first, in their conception, carefully managed; then, inside the magazine itself (in the editorial well for fashion and beauty photographic series) which establishes a symbolic and visual hierarchy at its core.

4. Jennifer Craik, The Face of Fashion: Cultural Studies in Fashion (London/New York: Routledge, 1994), 43 sq..

5. Vogue claimed a readership of 10 million in the 1970s, Harper's Bazaar of 1.8 million in the same period. Both high-end magazines, their targeted readership was mostly upper-class women until the late 1950s, when in a shifting editorial landscape they democratized and tried to attract a younger, more active audience-a strategy that also accounts for their larger reach from the late 1960s, and parallels the massification of perfume marketing from the same period on. 
6. Here, I am thinking of the writing of such different personalities as historian Alain Corbin, anthropologist Joël Candau, perfumer Jean-Claude Elléna, perfume curator Marie-Christine Grasse, Annick Le Guérer, who is attached to an Information and Communication research team and American specialist of French culture Richard Stamelman. See Alain Corbin, Le Miasme et la Jonquille. L'odorat et l'imaginaire social, XVIII ${ }^{\text {- }}$ XIXe siècles (Paris: Flammarion, 1982); Joël Candau, Mémoire et expériences olfactives. Anthropologie d'un savoir-faire sensoriel (Paris: Presses Universitaires de France, 2000) and Marie-Christine Grasse, Une histoire mondiale du parfum: Des origines à nos jours (Paris: Somogy Éditions d'art, 2007), besides the works cited below.

7. In the centuries preceding, perfumes and perfumery were associated with religion, pharmacy, haberdashery or even, in the 16th century, glove-making (Annick Le Guérer, "Le parfum, des temples égyptiens aux temples de la consommation," Mode de Recherche 11, (2009/1): 14-15).

8. Le Guérer, "Le parfum", passim.

9. Poiret, a famed couturier in the 1910s, as well as a socialite and a businessman, was the first to launch a dedicated perfume line, "Parfums Rosine", to tie it to his clothing line, and to work with famous illustrators such as Georges Lepape to commercialize it. 10. Anne-Sophie Trébuchet-Breitweiller, "Parfum et mode, l'histoire d'un paradoxe," Mode de Recherche 11, (2009/1): 20-22. The standardization of perfume and its images will be explored later in the paper.

11. It is indeed in the 1970s that the whole of the cosmetic industry (a longtime advertiser) booms and become very profitable (Geoffrey Jones, Beauty Imagined: A History of the Global Beauty Industry (Oxford: Oxford University Press, 2010)), an evolution to which magazines contributed and that they reported by increasing the amount of their beauty pages. Cosmetic conglomerates then turned to fashion's household names, who were licensed in order to sell perfume, make-up and eyeglasses. Said famous names helped these products appear glamorous, while they were also access products to more expensive lines of leather accessories, ready-to-wear and even couture.

The term "hyperconsumerism" has been coined by Gilles Lipovetsky, who thus qualifies the late, expanded and post-modern version of consumerism unfolding from the $1980 \mathrm{~s}$ on (Gilles Lipovetsky, "La société d'hyperconsommation," Le Débat 124, (2003)).

12. The 1960 s were indeed a rich decade for fashion, seeing notably the creative rise of the American business model of the ready-to-wear challenge French couture. On this topic and the uses of dress by political and countercultural movement, see the author's article, "The Fashion of the 1960s. A New Power Shaping the American Image," USAbroad 1 (2018/1).

https://usabroad.unibo.it/article/view/7162/7525.

13. Valerie Steele, Interview with the author (FIT New York, 2016).

14. In the 1970s, the great variety of forms in clothing (long or short, sober or ornamented, masculine or hyper-feminine inspired) originated from 1960s innovations. Yet, the spirit of dissent behind these new propositions in dress, which had a lasting impact and is today vividly remembered and debated (what I call the "mythified sixties") gradually faded in the 1970 s to the benefit of just form.

15. Craik, The Face of Fashion, 47-53.

16. Valerie Steele, “Anti Fashion: The 1970s," Fashion Theory 1, (1997/3): 280.

17. Edward D. Berkowitz, Something Happened: A Political and Cultural Overview of the Seventies (New York: Columbia University Press, 2006): 1-10.

18. The expression is from activist, turned writer and academic Todd Gitlin (1987). 
19. François Cusset, La décennie (Paris: La Découverte, 2008): passim.

20. Brian Moeran, "More Than Just a Fashion Magazine," Current Sociology 54, (2006): 734-737.

21. Dick Hebdige, Sub-culture. The Meaning of Style (London: Methuen \& Co. Ltd, 1979): 94 sq.. Hebdige's work has experienced great critical fortune in studies on "post-modern" fashion, and his theory of "recuperation" has been applied to many other developments in (fashion) trends, such as other subcultures such as grunge and hipster, as well as historical and exotic inspirations. See, for example, Caroline Evans "Street Style, Subculture and Subversion," Costume 31, (1997/1) and Claude Chastagner, De la culture rock (Paris: Presses Universitaires de France, 2011).

22. Fashion magazines, and especially traditional ones such as Vogue and Harper's Bazaar, are organized around strong calendar moments, for instance the March and September issues which present yearly the new collections after the bi-annual fashions shows. This seasonality is another proof of the pivotal relationship between advertisers and journalists, obligated to report on certain brands when the collection come out, for fashion but also for beauty and perfume. The May and November issues in which many perfume photoshoots are concentrated are by less prestigious, but still more important than the summer issues, which are smaller.

23. While the main argument of the present article is that increased focus on the staging of perfumes in magazines editorials can be explained, in this period, by the aesthetic and symbolic possibilities the former opened for the latter, economic reasons were, of course, also at play. In particular, as the proportion of beauty pages expanded in fashion magazines, so did their budget, too, allowing for more elaborate mises en scènes, engineered also to please advertisers. Let us also note that the production of fragrance-related content continued well into the 1980s, often still in same regular issues, designated to present perfume novelties, and that during this following decade, the de-materialization, market globalization, over-visualization, and "recuperation" originated in the 1970s gave their full measure.

24. Carolyn Kitch, The Girl on the Magazine Cover: The Origins of Visual Stereotypes in American Mass Media (Chapel Hill: University of North Carolina Press, 2001): 2-12.

25. See, for instance, Katharina Lindner, "Images of Women in General Interest and Fashion Magazine Advertisements from 1955 to 2002," Sex Roles 51, (2004/7-8).

26. Such an observation is concurrent with Valerie Steele's remark that music was of continued importance in fashion after the 1960s and in the aftermath of its countercultural ties, as was the case originally with the Hippies, for example (Steele, "Anti Fashion," 286).

27. The outdoors, casualness and Nature have been associated with American designs since the rise of ready-to-wear in the 1930s, as opposed to socially codified, indoor and evening-oriented European couture.

28. On women's magazines discourses in the 19th century, see Margaret Beetham, $A$ Magazine of Her Own?: Domesticity and Desire in the Woman's Magazine, 1800-1914 (Milton Park: Taylor \& Francis, 2004). On advertising in 20th century-Vogue see Daniel D. Hill, As Seen in Vogue: A Century of American Fashion in Advertising (Lubbock: Texas Tech University Press, 2007). On women and magazines, see Rachel Ritchie et al., eds, Women in Magazines:

Research, Representation, Production and Consumption (New York: Routledge, 2016).

On gendered propaganda shifting towards a restoration of conservative values at the end of World War II, see Hélène Le Dantec-Lowry, “To Speed Our Boys Home... Produce 
and Conserve. Share and Play Square. Home Front Propaganda and Food during World War II: Rewriting Gender?," Transatlantica (2018). On the importance of soft power during the "hot" period of the Cold War, see Gay McDonald, "The Modern American Home as Soft Power: Finland, MoMA and the 'American Home 1953' Exhibition," Journal of Design History 23 (2010/4).

It is to be noted that it is indeed this traditional model which contested, along with various forms of authority, in the 1960s and 1970s and which strongly reappears under a new guise in the 1980s, in fashion magazines amongst other media.

29. Céline Manetta et al., "Verbal Representation of Fragrances: Dependence on Specific Task," Journal of Applied Social Psychology 41, (2011/3): 672.

30. This particularly applies to the fashion magazines' advocating of women's liberation, a very ambivalent process, producing contradictory narratives in images and in writing.

31. Richard Stamelman, Perfume: Joy, Scandal, Sin - A Cultural History of Fragrance from 1750 to the Present (New York: Rizzoli, 2006): 17-18.

32. For more on this topic, see Christina Rain Bradstreet, Scented Visions: The NineteenthCentury Olfactory Imagination (Thesis submitted for the Degree of Doctor of Philosophy in History of Art, Birkbeck College, University of London, 2008).

33. Michael Gross, Focus: The Secret, Sexy, Sometimes Sordid World of Fashion Photographers (New York: Simon \& Schuster, Atria Books, 2016): 223-224; Alistair O'Neill, “Fashion Photography, Communication, criticisme and curation from 1975," in Fashion Cultures Revisited: Theories, Explorations and Analysis, eds. Stella Bruzzi and Pamela Church Gibson (London/New York: Routledge, 2013): 150-151.

34. Trébuchet-Breitweiller, "Parfum et mode", 20.

35. Jean-Claude Ellena and Olivier Assouly, "Entretien/Jean-Claude Ellena, Le parfum à l'épreuve des marchés," Mode de Recherche 11, (2009/1): 3-4.

36. Edgar Morin, L'esprit du temps. Essai sur la culture de masse (1962; La Tour-d'Aigues: Éditions de l'Aube, 2017); Gilles Lipovetsky, L'Empire de l'éphémère : La mode et son destin dans les sociétés modernes (Paris: Gallimard, 1987).

37. On intericonicity in fashion imagery see Julie Morère, "Intericonicity in Disguise in Madame Yevonde's Goddesses Series and Cindy Sherman's History Portraits/old Masters," E-Rea. Revue Électronique D'études Sur Le Monde Anglophone 13, (2015/1).

38. Catherine Têtu, "La présence des parfums en marge des parfums de masse," Mode de Recherche 11, (2009/1): 24.

\section{ABSTRACTS}

From the early 1970s until well into the 1980s, there was a dramatic increase in the attention granted to images of perfume in the editorial photographic production of two famous U.S. fashion magazines, Vogue and Harper's Bazaar-both mainstream, well-structured publications, having established leadership in their field. The momentum of these images-staging olfactory products and visually evoking the feelings, sensations, and memories conjured up by their smell -results from new formal photographic research led, in part, to negotiate socio-cultural flux deeply destabilizing society at large and these high-end magazines in particular. The outcome is a distinguishable aesthetic. Now considered representative of the period, it ultimately proved efficient in helping to ease changes into fashion magazines, and in feeding their powerful, longstanding system of references all the while announcing the turn to an ever-expanding consumerism blooming in the 1980s. In this process, the undeniable power of attraction, and 
seduction of images and smell, was once more commodified, making it emblematic of an editorial visual system that is still topical today.

INDEX

Keywords: editorial system; fashion photography; magazines; perfume; cultural history.

\section{AUTHOR}

\section{ALICE MORIN}

Alice Morin has just completed her $\mathrm{PhD}$ on the editorial system of fashion photography and women's representations in the American mainstream press from the 1960s to the 1980s at Université Sorbonne Nouvelle. She previously studied art history at the École du Louvre and American literature at the Sorbonne Nouvelle. 